\title{
Bisnis Sosial: Sintesis Muhammad Yunus untuk Menggerakkan Kapitalisme di Bangladesh
}

\author{
Lucitania Rizky \\ International Relations Research Center, Jurusan IImu Hubungan Internasional, Fakultas IImu Sosial \\ dan IImu Politik, Universitas Muhammadiyah Yogyakarta \\ Ringroad Barat Tamantirto, Kasihan, Bantul 55183 \\ Email: lucitaniamahjum@yahoo.com \\ Diterima pada 10 Maret 2015, Disetujui pada 25 Maret 2015
}

\begin{abstract}
The emerge of Social Business offers a new kind of capitalism in some developing countries. This manifestation of capitalism concept has introduced by Muhammad Yunus as a respond to vicious cycle poverty in Bangladesh. Grameen Bank has been creating a solid relation between capitalism and poverty. By using the people center development perspective and sustainable development concept, this article tries to elaborate the friendly of capitalism pattern to the poor and its development agenda. This article assured that the relation development. Key Words: Social Business, capitalism, Grameen Bank, people center development, sustainable development.
\end{abstract}

\begin{abstract}
Abstrak
Bisnis Sosial hadir sebagai sebuah tawaran baru atas eksistensi kapitalisme di beberapa negara berkembang di dunia. Manifestasi dari konsep kapitalisme ini dihadirkan oleh Muhammad Yunus untuk menjawab kegelisahan atas permasalahan kemiskinan yang tak kunjung usai di Bangladesh. Grameen Bank mendorong terciptanya suatu hubungan yang solid antara kapitalisme dengan kemiskinan. Dengan menggunakan pandangan people center development dan konsep sutainable development, artikel ini mencoba untuk menguraikan pola kapitalisme yang ramah kepada kaum miskin dan memiliki agenda pembangunan yang berkelanjutan. Artikel ini menegaskan bahwa hubungan antara kapitalisme dengan kemiskinan sejatinya dapat dikolaborasikan

Kata Kunci: Bisnis Sosial, kapitalisme, Grameen Bank, people center development, sustainable development.
\end{abstract}

\section{PENDAHULUAN}

Kehadiran Bisnis Sosial ditengah hiruk pikuk kemiskinan membawa nafas kehidupan baru bagi rakyat kecil Bangladesh. Telah sedikit disinggung dalam pemaparan sebelumnya, bahwa kehadiran Bisnis Sosial sebagai tawaran baru di tengah eksistensi kapitalisme yang melakukan eksploitasi terhadap sumber kesejahteraan rakyat.Yunus ingin mencapai cita-cita pembangunan berkelanjutan, maksudnya menggeser titik berat pembangunan dari yang awalnya pembangunan hanya dalam aspek ekonomi menjadi memiliki cakupan pembangunan pada aspek sosialbudaya dan aspek lingkungan hidup. Kerangka ini akan mewujudkan bentuk baru atas kinerja kapitalisme bagi kaum miskin dan melahirkan pembangunan yang berkelanjutan di Bangladesh.

\section{KAPITALISME, YUNUS, DAN KAUM MISKIN}

Proteksionisme ekonomi, subsidi, dan tunjangan kesejahteraan dilembagakan oleh orang-orang yang bermaksud untuk melunakkan sisi keras kapitalisme (Nasution, 2007: 199). Inilah yang biasa dilakukan oleh negara berkembang di dunia, berbeda dengan langkah Muhammad Yunus dalam melunakkan sisi keras kapitalisme. Yunus mencoba untuk 
mengkolaborasikannya dengan sistem ekonomi dan nilai-nilai kehidupan setempat. Filantropi, pasar bebas, kegiatan ekonomi secara privat, dan mencari keutungan secara maksimal, merupakan macam kegiatan kapitalisme dan masih dianggap wajar sebagai rutinitas kegiatan ekonomi (Big Think - You Tube, Muhammad Yunus on Captalism, 2012).

Bagi Muhammad Yunus, globalisasi yang digadanggadang sebagai media penyebaran kapitalis, merupakan jalan untuk mendapatkan banyak keuntungan dari proses penetrasi itu sendiri. Seperti mobilisasi MNC, korporasi atau perusahaan asing ke negara-negara berkembang. Namun, globalisasi dalam beberapa kasus bereperan sebagai imperealisme finansial, maksudnya sebuah tindakan yang hanya masuk dan menjajah secara finansial tanpa adanya proses pembangunan yang berkelanjutan.

Yunus bukanlah seorang kapitalis dalam pengertian simplistik seperti yang dipahami kaum kiri dan kaum kanan. Dalam konteks pengentasan kemiskinan dan penyelesaian masalah sosial lain, Yunus menentang atas tunjangan yang diberikan oleh korporasi asing atau corporate social responbility (CSR) sebagai jawaban terhadap masalah kemiskinan. Kaum miskin yang secara fisik sehat tidak membutuhkan tunjangan 'sesaat', melainkan mereka lebih membutuhkan modal untuk mengakses sumber kesejahteraan. Konsep ini hanya akan tetap melanggengkan kehadiran kapitalisme yang ekploitatif, merampas insentif kaum miskin atas kekayaan alam dan membatasi mereka dalam mengembangkan kemampuan diri (New Internaionalist, 1994).

Konsep Bisnis Sosial yang ditawarkan oleh Yunus bersifat hibrida. Maksudnya, sebagian mengambil sisi baik dari kapitalisme dan sebagian lain tetap melestarikan sistem sosial-ekonomi sesuai budaya pada masyarakat setempat, Bangladesh. Yunus percaya bahwa dalam menganut kapitalisme secara utuh tanpa mempertimbangkan kondisi masyarkat sekitar hanya akan menghasilkan sebuah sistem yang pincang.

Menurut Yunus, dalam tubuh kapitalisme terdapat bagian yang hilang. Hal ini yang menjadi momok kerusakan kinerja kapitalisme dalam menghadapi berbagai macam situasi kehidupan di setiap tingkatan masyarakat. Muhammad Yunus menyebutnya sebagai incomplete capitalism. Produk-produk Bisnis Sosial yang ditawarkan menjadi barang nyata atas bentuk pergeseran dari incomplete capitalism menjadi complete capitalism. Kapitalisme yang 'cacat' dapat diperbaiki dan dikembangkan kembali, sehingga kapitalisme dapat berkontribusi dalam penyelesaian permasalahan kemiskinan.

Ciri kapitalisme yang digambarkan pada buku Bank Kaum Miskin oleh Muhammad Yunus adalah memaksimalkan laba dan memastikan pemanfaatan sumber daya yang langka secara optimal. Inilah ciri kapitalisme yang menggiring konstruksi pikiran kita terhadap sesuatu yang tamak dalam upayanya mendapatkan laba. Akibatnya, muncul pandangan dari masyarakat miskin bahwa orang yang beorientasi laba tidak memiliki kepentingan dalam pencapaian tujuantujuan sosial.

Hal ini membuat eksistensi kapitalisme di Bangladesh diragukan oleh Yunus dalam menyelesaikan masalah kemiskinan maupun sosial. Kelemahan mendasar dari teori kapitalisme menurut Yunus terletak dalam penjabarannya mengenai ciri dasar manusia. Kapitalisme menjabarkan manusia sebagai makhluk satu dimensi dengan tujuan tunggal, yaitu memaksimalkan keuntungan. Manusia dianggap oleh kaum kapitalis, sebagai individu yang hanya mengejar ekonomi dan kesejahteraan materi. Yunus berpendapat bahwa manusia bukanlah robot pencetak uang. Akan tetapi, manusia merupakan makhluk yang berdimensi banyak. Kebahagian manusia dan masyarakat secara umum tidak hanya datang dari orientasi uang (Kantjono, 2011: xix). Masyarakat miskin di desa-desa Bangladesh, misalnya, Yunus menempatkan mereka sebagai agen Bisnis Sosial yang memiliki peran ganda. Mencari keuntungan sekaligus menjalankan peran bisnis sebagai makhluk sosial.

Tidak dapat disangkal bahwa salah satu tantangan terbesar yang dihadapi semua negara berkembang adalah kemiskinan dari sebagian besar rakyatnya, tidak terkecuali Bangladesh. Untuk mengatasi masalah besar ini, menjalankan pembangunan ekonomi menjadi 
sebuah keharusan. Namun, pemahaman atas kemiskinan yang cenderung menfokuskan pada material-ekonomi harus dihilangkan. Kemiskinan itu mempunyai dimensi yang lebih luas. Kemiskinan adalah sebuah kondisi kehidupan yang memiliki banyak wajah. Bencana ini harus didekati dari berbagai sudut, dan tidak ada pendekatan yang dapat dianggap lebih penting dari pendekatan yang lain (Nasution, 2007: 57). Kemampuan manusia harus dapat dikembangkan dan ditingkatkan agar tekanan kepada sumber daya alam dalam mengatasi kemiskinan dapat diperkecil.

Konsep sustainable development hadir dan menawarkan penjelasan yang sesuai dan tepat terhadap penjabaran kondisi di atas. Konsep ini, menunjukkan adanya kekeliruan dalam memposisikan manusia dan pola pembangunannya.Pembangunan ekonomi kapitalis hanya berorientasi pada perbaikan standar kehidupan, khususnya standar material. Tercapainya kesejahteraan material seakan menjadi hal utama bagi hidup manusia. Aspek-aspek lain dari kesejahteraan manusia, seperti kemajuan budaya, spiritual, dan estetika, tidak diperhitungkan sama sekali, hanya uang, materi, dan kemewahan sevbagai orientasi utama.

Padahal, jalan untuk mendapatkannya adalah dengan menguras habis kekayaan alam yang ada dan mereduksinya semata-mata sebagai nilai ekonomis (Keraf, 2002: 171-172). Hal ini menjadi suatu kekeroposan dalam tubuh kapitalis yang diamati oleh Yunus di Bangladesh.

Tidak menjadi sebuah masalah ketika sistem kapitalis menuntut untuk mendapatkan keuntungan yang lebih banyak dari pengolahan sumber daya alam. Ambil contoh, korporasi asing seperti Shell Bangladesh Exploration $\mathcal{E}$ Development B.V yang melakukan eksploitasi terhadap tambang minyak dan gas di Bangladesh, kemudian dijual kembali di pasar global. Namun, tindakan ini harus diperhitungkan nilai-nilai ekologisnya. Yunus sepakat dengan konsep sustainable development, bahwa dalam melakukan pengolahan sumber daya demi memenuhi kesejahteraan sekelompok orang jangan sampai malah mengorbankan nilai-nilai yang lebih mahal.
Berangkat dari pemikiran yang telah dijabarkan sebelumya, Yunus mencetuskan Bisnis Sosial sebagai bentuk nyata atas pemikirannya mengenai sintesis kapitalisme. Bisnis Sosial membuka diri atas kedatangan modal-modal dari perusahaan asing yang masuk ke Bangladesh dan memberikan kesempatan kepada kaum miskin sebagai aktor utama penggiat pembangunan di Bangladesh untuk mengelolanya. Dalam menjalankan agenda pembangunan, Muhammad Yunus memberikan jangkauan tegas atas pelaksanaan pembangunan yang bersifat berkelanjutan dan tidak eksploitatif. Ini menjadi agenda besar dalam revolusi pembangunan di Bangladesh yang dicetuskan oleh Yunus.

Dalam World Summit 2005 menyebutkan bahwa pembangunan yang berkelanjutan tidak saja berkonsentrasi pada isu-isu lingkungan. Lebih luas daripada itu, pembangunan berkelanjutan mencakup tiga lingkup kebijakan: pembangunan ekonomi, pembangunan sosial, dan pembangunan ekonomi. Ketiga dimensi ini saling terkait dan merupakan pilar pendorong bagi pembangunan berkelanjutan.

Dilain sisi, Muhammad Yunus percaya pada tesis pokok kapitalisme, yang menyatakan bahwa sistem ekonomi yang berlangsung diharuskan bersifat kompetitif. Kapitalisme yang kompetitif melahirkan sebuah persaingan, dimana hal ini diartikan sebagai kekuatan penggerak seluruh inovasi, perubahan teknologi, dan perbaikan manajemen. Tesis pokok kapitalisme ini akan digunakan oleh Yunus dalam menggerakan semangat kewirausahaan bagi kaum miskin di Bangladesh.

Muhammad Yunus kemudian mengajukan dua perubahan terhadap ciri mendasar kapitalisme. Pertama, terkait dengan gambaran masyarakat terhadap seorang pengusaha kapitalis. Bagi Yunus, seorang pengusaha bukanlah seseoarang yang memiliki bakat khusus. Rumusan Yunus adalah semua orang manusia - adalah pengusaha potensial. Kedua, keharusan bagi seorang pengusaha untuk mempertimbangkan aspek sosial-budaya dan aspek lingkungan sekitar sebelum melakukan investasi di sebuah tempat. Diharapkan agar nilai investasi dari 
perusahaan mereka akan memiliki sifat kontinyuitas.

Integrasi ekonomi Bangladesh terhadap ekonomi global tidak disalahkan oleh Yunus seutuhnya. Hal tersebut dianggap wajar sebagai salah satu bentuk perilaku negara dalam kehidupan global. Namun, sangat disayangkan bahwa 'pola' ini membawa Bangladesh semakin berada pada keadaan kemiskinan ekstrim. Agenda-agenda yang dijanjikan tidak menghasilkan mimpi-mimpi kemakmuran nyata.

Yunus percaya bahwa manusia sebagai makhluk individu dapat menyelesaikan permasalahan dirinya maupun sekitar ketika mendapat porsi untuk ikut serta dalam pengolahan sumber kapital. Setiap individu di dunia memiliki potensi dan hak untuk hidup layak, bahkan bagi masyarakat termiskin dari orang-orang miskin. Dalam pandangannya, Yunus tidak mempersoalkan aliran modal dari para pemilik uang atau korporasi asing ke Bangladesh, namun agenda-agenda pembangunan tidak selayaknya berpusat pada aturan-hukum korporasi. Muhammad Yunus merumuskan bahwa sejatinya, kapital atau modal adalah 'teman' dari kaum miskin dan akumulasi kapital yang berasal dari kaum miskin merupakan cara terbaik untuk melarikan diri dari kemiskinan.

\section{PEMBAHASAN}

GRAMEEN BANK: PEMBANGUNAN YANG BERKELANJUTAN

Konsep pembangunan atau lebih tepatnya program pengentasan kemiskinan harus didefinisikan kembali. Pembangunan yang selama ini dipraktikan oleh dunia kapitalis jelas tidak menjanjikan bagi kesejahteraan masyarakat. Maka, Yunus melakukan re-definisi terhadap pembangunan yang dimanifestakisan dalam bentuk Grameen Bank. Pembangunan dalam konteks Grameen Bank adalah sebuah proses perubahan sosialpolitik-ekonomi yang komlpeks, dimana bagian yang satu tidak dapat dipisahkan dengan bagian yang lain (Nasution, 2007: xiv).

Grameen Bank didirikan sebagai perwujudan nyata atas konseptualisasi Bisnis Sosial. Pada awalnya, Grameen Bank terbentuk dari sebuah langkah sederhana Muhammad Yunus dalam membebaskan kaum miskin - perempuan - atas lilitan hutang kepada lintah darat di Desa Jobra. Yunus dikejutkan dengan fakta 42 perempuan rumah tangga yang meminjam modal sebesar 5 taka (atau sekitar 7 sen dollar Amerika) dari para lintah darat (Beim, 2004: 2). Mereka menggunakan uang tersebut guna membeli bambu, yang kemudian mereka anyam hingga menjadi kursi siap jual. Suku bunga atas pinjaman kecil seperti ini sangat tinggi, mencapai $10 \%$ per-minggu. Keadaan yang lebih buruk terjadi ketika hasil produksi bambu tersebut harus dijual kepada lintah darat dengan harga yang telah ditentukkan oleh pihak pembeli (Kantjono, 2011: x).

Fenomena ini dilihat sebagai sebuah 'lingkaran setan' yang memaksa kaum miskin untuk tetap berada di bawah kendali para pemilik modal. Yunus melakukan sebuah perubahan aksi kecil yang diwujudkan dengan pemberian uang kepada para peminjam modal (42 perempuan rumah tangga di Desa Jobra) untuk melunasi hutang. Kegembiraan tercipta di Desa Jobra sesaat setelah aksi kecil yang dilakukan oleh Yunus. Langkah kecil seperti ini bisa merubah keadaan yang awalnya suram menjadi harapan. Dari sinilah, Yunus terdorong untuk melakukan suatu perubahan yang lebih banyak.

Kaum miskin, terutama perempuan di Bangladesh telah berada jauh dari sumber-sumber kesejahteraan. Akses kaum perempuan terhadap modal di negaranegara berkembang lebih sempit dibanding dengan laki-laki. Meski demikian, perempuan tetap berurusan dengan kebutuhan keluarga sehari-hari (The Times, 1998: 5). Mereka bekerja sebagai budak dari para lintah darat untuk tetap bertahan hidup. Apakah ini keberhasilan sistem kapitalis yang dibanggakan? Korporasi asing - perbankan global telah menolak untuk memberikan dana suntikkan atau pinjaman modal kepada kaum miskin. Apakah hanya orang atau kelompok mayarakat tertentu yang mendapatkan perlakuan istimewa dari negara dalam proses pembangunan, khususnya dalam mendapatkan peluang dan akses terhadap sumber-sumber ekonomi (Keraf, 2002: 177)?

Di sini Yunus merumuskan jalan tengah, Bisnis Sosial, bagi penyelamatan para kaum miskin 
Bangladesh di tengah hiruk pikuk ekonomi kapitalis di tingkat nasional maupun global. Nobel Prize telah mengakui atas kesuksessan kredit mikro Muhammad Yunus yang menjadi kekuatan baru dalam pembebasan masyarakat, khususnya perempuan, dalam berjuang melawan kondisi sosial dan ekonomi yang represif.

Grameen Bank sebagai langkah awal dari Bisnis Sosial dijalankan sesuai dengan tiga prinsip pembangunan berkelanjutan, yaitu: prinsip demokrasi, prinsip keadilan, dan prinsip keberlanjutan. Aspek pembangunan ekonomi, sosial-budaya, dan lingkungan hidup hanya mungkin dicapai jika ketiga prinsip dasar ini dioperasionalkan sebagai sebuah politik pembangunan (Keraf, 2002: 177). Pertama, prinsip demokrasi, agenda utama pembangunannya merupakan agenda rakyat demi kepentingan rakyat. Inilah yang menjadi dasar Grameen Bank bekerja, bahwa kepemilikkan saham, peminjaman uang, dan berputarnya uang semua dikelola oleh rakyat dan untuk kepentingan rakyat miskin di Bangladesh. Deviden dari Grameen Bank juga akan dimanfaatkan guna pengembangan usaha Grameen itu untuk kemadirian dan kesejahteraan rakyat.

Kedua, prinsip keadilan, prinsip ini pada dasarnya ingin menjamin bahwa semua orang dan kelompok masyarakat memperoleh peluang yang sama untuk ikut dalam proses pembangunan dan kegiatan-kegiatan produktif, serta ikut dalam menikmati hasil pembangunan. Pada awalnya, masyarakat miskin di desa-desa di Bangladesh tidak memiliki akses yang baik dalam menikmati hasil pembangunan yang diupayakan oleh pemerintah pusat. Mereka berada dalam posisi yang termarjinalisasi terutama oleh bank-bank konvensional pemegang modal. Dalam kaitan dengan hal ini, tindakan politik afirmatif diperlukan guna membantu kelompok masyarakat yang tidak mempunyai peluang dan akses yang sama, karena terpencil, kurang prasarana, kurang pendidikan, dan sebagainya. Demikian pula, harus ada tindakan politik afirmatif bagi kelompok tertentu, khususnya kelompok perempuan yang mungkin menjadi rentan akibat dampak dari proses pembangunan, temasuk dampak lingkungan hidup (Shiva, 1997: 7).
Grameen Bank diinisiasi guna menjembatani persoalan tersebut. Grameen berarti desa, Yunus memberi nama bank ini sebagai 'Bank Pedesaan'. Grameen Bank dibentuk guna melayani masyarakat kecil, khususnya perempuan dalam mendapatkan pinjaman modal berupa mikrokredit dengan lebih mudah, aman, dan berkelanjutan. Selain itu, Bank Kaum Miskin ini juga membantu masyarakat yang diperlakukan secara tidak adil atau termarjinalisasi oleh keberadaan perbankan asing, karena faktor kemiskinannya dalam mendapatkan pinjaman.

Cara kerja Grameen Bank berbeda dengan perbankan konvensional. Grameen Bank memberikan pinjaman tanpa beban anggunan dari peminjam kaum miskin -. Administrasi yang disyaratkan oleh Grameen Bank tidak serumit seperti bank-bank biasanya. Gramen Bank bekerja menyesuaikan dengan keadaan kaum miskin. Mayoritas penduduk pedesaan masih mengalami tingkat kebutaan huruf yang tinggi, mereka mendapati kesulitan dalam mengisi form pinjaman atau penyetoran seperti yang terjadi di bank konvensional. Di Grameen Bank kaum miskin tidak diharuskan mengisi administrasi secara tertulis, karena hal ini akan dilakukan oleh pekerja Grameen Bank dalam proses pencatatannya. Selain itu, bunga yang diberikan sangat rendah (mendekati 0\%) dan dikembalikan dalam kurun waktu yang lama.

Kemudahan lain dari Gramenn Bank adalah jasa bank yang datang kepada setiap nasabah, bukan nasabah yang datang ke Bank. Hal ini berdasar pada pengamatan Yunus, bahwa masyarakat miskin lebih memilih untuk melakukan pekerjaan rumah, seperti bertani dan menganyam daripada mereka harus datang ke bank dan mengantri. Kerangka kerja bank yang seperti ini dibutuhkan untuk melakukan penyeimbangan antara aspek ekonomi dan aspek sosial.

Ketiga, prinsip keberlanjutan, prinsip yang mengharuskan kelompok masyarakat miskin dan Yunus bersinergi merancang agenda pembangunan dalam dimensi visioner jangka panjang. Prinsip ini guna mengevaluasi dampak pembangunan baik postif maupun negatif dalam segala aspek (Keraf, 2002: 179- 
180). Keberlanjutan Grameen Bank dilakukan mengingat perannya sebagai program kredit dengan tujuan pengentasan kemiskinan, kemampuan organisasi dan penyelesaian masalah sosial lain. Dalam sebuah review dari The Times, menyatakan atas dukungannya terhadap kinerja mikrokredit - Grameen Bank untuk melakukan ekspansi kerja sosial yang lebih luas, seperti: kesetaraan gender, kontrol terhadap angka kelahiran, dan lingkungan hidup. Grameen Bank menggunakan sumber bersubsidi untuk membiayai kegiatan produktif bagi masyarakat miskin. Sehingga, Grameen Bank dituntut untuk melakukan kerjasama guna mendapatkan modal secara mandiri (Khandker et.al, 1994: 8-9).

Demi mendukung keberlanjutan agenda, Yunus melakukan perluasan jangkauan kerja Bisnis Sosial. Dalam mendapatkan sumber dana dan menyelesaikan masalah sosial - lingkungan, maka Muhammad Yunus akan melakukan usaha patungan dengan beberapa korporasi asing. Korporasi yang memiliki sumber kapital dimanfaatkan oleh Yunus guna kemaslahatan masyarakat miskin dengan mempertimbankan konsekuensi-konsekuensi alam. Beberapa contoh bentuk keberlanjutan Grameen Bank adalah kerjasamanya dengan Otto $\mathrm{GmbH}$ dari Jerman. Otto $\mathrm{GmbH}$ adalah sebuah perusahaan perdagangan dan mail order yang menangani tekstil serta produk-produk lain. Selain memberi dana suntikan kepada Grameen, perusahaan Otto ini juga melakukan kolaborasi pendirian pabrik untuk pakaian ekspor. Usaha yang dibangun, Otto Grameen merealisasikan nilai-nilai pembangunan yang berkelanjutan dalam hal ekologi lingkungan. Hal ini terbukti dengan pertimbangan atas fasilitas pabrik Grameen Otto yang diusahakan menghasilkan karbon netral (Kantjono, 2011: 208).

Ini merupakan bentuk komitmen nyata dari Bisnis Sosial dalam mempertimbangkan aspek orientasi pembangunan lain. Grameen Bank menjadi cikal bakal terbentuknya bisnis grameen yang lebih banyak dan variatif di tanah kemiskinan Bangladesh. Disisi lain, Yunus membentuk Grameen Not for Profit sebagai konsistensinya menjalankan konsep pembangunan berkelanjutan. Berikut disampaikan sektor-sektor
Tabel 1

Grameen Not for Profit
Nama Grameen Not For Profit

Grameen Shakti

Grameen Trust

Grameen Shikkha

Grameen Byabosha

Bikash

Grameen

Communications

Grameen Healthcare Services

Grameen Kalyan

Grameen Krishi Foundation

Grameen Healthcare Trust

Grameen Uddog and Grameen Shamorgree
Grameen Fund
Sektor Pembangunan Berkelanjutan

Pembangunan Energi Matahari (solar energy)yang berkelanjutan

Mikrokredit - membantu menyelesaikan permasalahan kemiskinan

Pendidikan bagi anak-anak dan kaum muda yang tidak mampu mendapatkan akses pendidikan dengan baik

Menghubungkan para produsen desa kepada pangsa pasar tanpa perantara Penyedia produk perangkat lunak dengan kualitas tekemuka, seperti layanan internet bagi kemaslahatan kaum miskin

Memberikan servis kesehatan yang lebih baik kepada kaum miskin

Asuransi kesehatan primer bagi masyarakat miskin

Kegiatan pertanian untuk mengentaskan kemiskinan di kalangan petani miskin dan marginal. Swasembada meningkatkan pemanfaatan efektif dari sumber daya pertanian.

Strategi untuk menyediakan pembiayaan modal usaha, terutama dalam usaa berbasis teknologi.

Menyediakan lahan kredit mikro bagi perawatan kesehatan Pembiayaan industri pedesaan dan memasarkan produk mereka, terutama produksi padat karya di Bangladesh dan luar negeri. produksi pangan serta

Sumber: Yunus Center - Not for Profit. Lihat lebih jelas pada (http://www. muhammadyunus.org/, diakses pada 30 Oktober 2014).Data sudah diolah penulis.

pembangunan berkelanjutan.

Grameen Bank tidak hanya bekerja demi mendapatkan kepuasan dalam memenuhi materi dan mengejar deviden atau keuntungan. Selebihnya, 
Grameen Bank juga meletakkan perhatian terhadap aspek sosial-budaya. Hal ini diwujudkan oleh Muhammad Yunus dalam mendorong jiwa kewirausahaan bagi setiap peminjam di Grameen Bank. Masyarakat miskin Bangladesh harus dapat menggunakan modal dari Grameen Bank untuk memulai sebuah bisnis baru, keuntungan yang didapat digunakan untuk kehidupan sehari-hari dan sisanya untuk menyicil pinjaman setiap minggunya di Grameen Bank.

Yunus berhasil mematahkan asumsi para perbankan konvensional mengenai kelayakkan kaum miskin dalam mendapatkan sumber modal. Hal ini dibuktikkan dengan kedisiplinan kaum miskin, peminjam uang di Grameen Bank, yang menyetorkan uang cicilan dengan tepat waktu kepada petugas Grameen Bank. Peminjam Grameen Bank oleh perempuan mencapai 94\% dari jumlah keseluruhan dan lebih dari 98\% peminjaman dikembalikan dengan baik dan tertib. keberhasilan ini menjadi indikator bahwa tingkat pemulihan kemiskinan oleh Grameen Bank lebih tinggi daripada sistem perbankan lainnya. John Elkington, seorang konsultan yang menangani startegi pembangunan berkelanjutan, berpendapat bahwa potensi kekuatan "kapitalisme baru" dalam mengubah kehidupan orang miskin menjadi lebih baik telah terbukti dengan lahirnya mikro kredit pada Grameen Bank.

Dengan pinjaman modal yang diberikan oleh Grameen Bank, kaum miskin di desa dapat menjalankan roda perekonomian mandiri tanpa harus bergantung kepada para lintah darat. Anggotaanggotanya memperoleh kesejahteraan perorangan, mereka dapat memiliki rumah, kaskus,pompa air, pendidikan akses ke layanan kesehatan,dan sebaginya. Fakta ini membuktikkan bekerjanya prinsip pembangunan berkelanjutan dengan memberikan peluang dan akses yang harus terbuka secara sama bagi semua orang dan kelompok. Grameen menjadi salah satu badan yang kemudian didefinisikan sebagai bank swasta swadaya.

Sesuai dengan konsep sustainable development bahwa pendirian Grameen Bank oleh Muhammad Yunus tidak hanya pada penyelesaian masalah ekonomi, namun juga empowerring women dalam pembentukan karakter, tanggung jawab, dan keaktifan dalam organisasi. Antusiasme dari para perempuan dan peminjam modal lain dalam berkontribusi pada Grameen Bank memiliki kenaikan yang cukup signifikan setiap tahunnya hingga beberapa kurun waktu terakhir (lihat Grafik 1).

\section{Grafik 1}

\section{Pertumbuhan Keanggotaan Grameen Bank, 1980 -} 2010

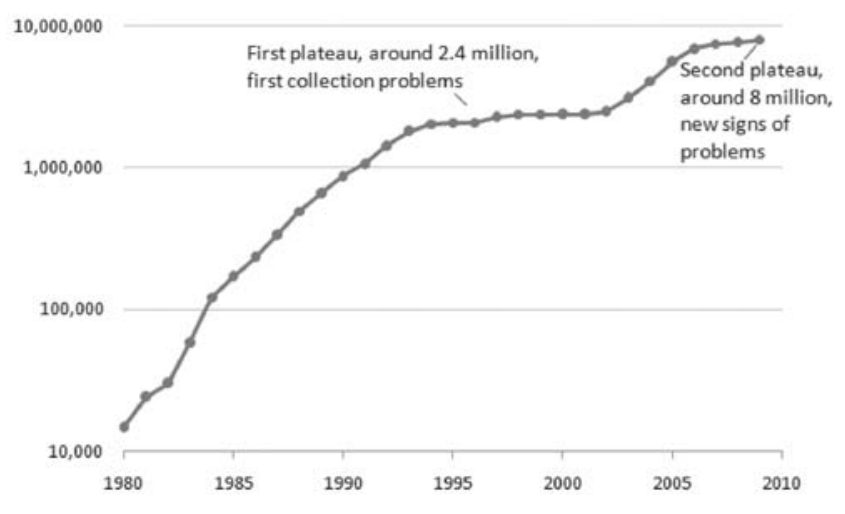

Sumber: Grameen Bank, Which Pioneered Loans for the Poor, Has Hit a Repayment Snag, By David Roodman, 2 September 2010 (http://www.cgdev.org/, diakses 30 Oktober 2014).

Grafik ini menjelaskan pertumbuhan pertahun dari Grameen Bank sejak 1980 hingga 2010. Masyarakat miskin Bangladesh mendapat keuntungan dari keberadaan Grameen Bank, sehingga hal ini menunjukan bahwa Grameen memiliki keberlanjutan yang baik.

Indikator pertumbuhan Grameen Bank tidak lepas dari strategi kerja yang dimiliki oleh Grameen tersebut. Berikut disampaikan ringkasan atas strategi Grameen Bank dan pertumbuhannya:

(Lihat tabel 2)

Tabel 2 menggambarkan bahwa kinerja Grameen Bank mengalami kemajuan yang pesat. Hal ini menjadikan Grameen Bank sebagai batu loncatan bagi lahirnya bisnis sosial lain yang dikembangkan bersama perusahaan asing. Keberhasilan sistem mikrokredit yang digunakan oleh Grameen Bank dalam penuntasan kemiskinan menjadi perbincangan para pebisnis barat. Bahwa ini merupakan langkah nyata dari Yunus atas bencana kemiskinan yang hadir di tengah agenda 
pembangunan besar oleh pemerintah Bangladesh.

\section{Tabel 2}

Ringkasan Strategi \& Pertumbuhan Grameen Bank

\begin{tabular}{ll}
\hline Strategi & Memiliki target klien yang unik \\
& - sebagaian besar adalah \\
& perempuan desa \\
- & Mengintegrasi tujuan sosial dan \\
& keuangan, dan menciptakan \\
& kemitraan yang langgeng \\
& dengan komunitas mikro kredit \\
& untuk pertumbuhan basis \\
& mikro kredit dunia \\
- & Lobi kepada organisasi \\
& pemerintah untuk \\
& meningkatkan visibilitas inisiatif \\
& keuangan mikro \\
- & Grameen Bank sudah tidak \\
& menerima bantan keuangan \\
& atau bersifat mandiri sejak \\
& tahun 1995. \\
- & $90 \%$ dana pinjaman berasal \\
& dari pendapatan dan deposito \\
Pertumbuhan & Dimulai dengan bisnis \\
& "Grameen" dengan resiko yang \\
& terbatas terhadap komitmen \\
& pinjaman kecil, organisasi- \\
& organisasi nya berjalan dengan \\
& entitas independen. \\
&
\end{tabular}

Sumber: Grameen Bank: Taking Capitalism to the Poor by David O. Beim (Beim, 2004: 14).

Keberhasilan Yunus dalam membangun microcredit telah diapresiasi oleh sejumlah tokoh dunia. Dalam sebuah review, Hungry Mid Review, Tom McInerney menyatakan bahwa seiring berjalannya waktu model Yunus telah terbukti sangat sukses. Sejak pinjaman awalnya di tahun 1976, peminjaman oleh bank terus tumbuh hingga saat ini. Kesuksessan terbukti dengan kemunculan proyek Grameen di berbagai tempat, seperti Vietnam, China, Filiphina. Kegigihannya dalam menghindari keterlibatan ahli pembangunan internasional dalam penyelamatan kaum miskin juga diakui oleh Tom (Hungry Mind Review, 1999).

Ditegaskan oleh Yunus dalam buku Bank Kaum
Miskin, bahwa kemiskinan tidak diciptakan oleh kaum miskin. Kemiskinan diciptakan oleh struktur masyarakat dan kebijakan-kebijakan yang dijalankan oleh masyarakat. Dengan mengubah struktur seperti yang dilakukan oleh Yunus, maka kita akan menyaksikan bahwa kaum miskin akan mengubah nasib mereka sendiri. Grameen menunjukan bahwa sekecil apa pun dukungan modal keuangan yang diberikan, kaum miskin sepenuhnya mampu meningkatkan kehidupan mereka.

\section{KOLABORASI GRAMEEN BANK DENGAN KORPORASI GLOBAL}

Dalam rangka mewujudkan sintesis kapitalisme, Muhammad Yunus melakukan perpaduan yang apik antara korporasi global dengan usaha Grameen nya. Hal ini dikenal sebagai usaha patungan antara peusahaan-perusahaan Grameen dan perusahaanperusahaan multinasional ternama.

Biasanya, pembangunan bersama dengan korporasi global cenderung menggunakan pola developmentalisme. Menurut konsep pembangunan berkelanjutan, pola ini hanya mengutamakan kemajuan ekonomi, seperti proses pembangunan yang terjadi di negara Barat. Pola developmentalisme harus ditinggalkan dan diganti dengan sebuah pendekatan yang lebih holistik dan integratif dengan memberi perhatian serius kepada pembangunan sosial-budaya dan lingkungan hidup. Kemajuan ekonomi yang dicapai selama ini di negara berkembang, termasuk Bangladesh, bersifat semu sekaligus membawa kerugian yang sangat mahal di sisi sosial-budaya dan lingkungan hidup (Keraf, 2002: 169).

Dalam menjalankan bisnis patungan dengan korporasi asing, Muhammad Yunus memberlakukan aturan-aturan yang harus diikuti dan disetuji oleh pihak korporasi sebelum bisnis berjalan. Menanggapi aturan-aturan yang ditawarkan, beberapa korporasi asing memberikan tanggapan positif. Seperti yang dinyatakan oleh chairman Intel, Craig Brenet, atas ketertarikannya kepada binsis sosial dan berniat untuk meluncurkan kerjasama bisnis sosial menggunakan beberapa teknologi informasi Intel agar bermanfaat 
bagi warga miskin (Yunus Center, 2011). Intel meupakan salah satu korporasi besar dunia dalam bidang teknologi yang berasal dari Negara Paman Sam.

Tabel 3

Daftar Korporasi yang Berkolaborasi dengan Grameen Bank

\begin{tabular}{|c|c|c|c|}
\hline Korporasi & $\begin{array}{l}\text { Negara } \\
\text { Asal }\end{array}$ & $\begin{array}{l}\text { Sektor dan Area } \\
\text { Kerjasama }\end{array}$ & $\begin{array}{l}\text { Hasil } \\
\text { Kolaborasi }\end{array}$ \\
\hline Danone & Prancis & $\begin{array}{l}\text { Makanan bagi } \\
\text { Kesehatan Anak }\end{array}$ & $\begin{array}{l}\text { Grameen } \\
\text { Danone }\end{array}$ \\
\hline BASF & Jerman & $\begin{array}{l}\text { Lingkungan dan } \\
\text { Kesehatan } \\
\text { (Kelambu } \\
\text { Nyamuk) }\end{array}$ & $\begin{array}{l}\text { BASF } \\
\text { Grameen }\end{array}$ \\
\hline $\begin{array}{l}\text { Veolia Water } \\
\text { (Veolia } \\
\text { Enviroment) }\end{array}$ & Perancis & $\begin{array}{l}\text { Fasilitas } \\
\text { pengolahan } \\
\text { sumber daya air }\end{array}$ & $\begin{array}{l}\text { Grameen } \\
\text { Veolia } \\
\text { Water }\end{array}$ \\
\hline Intel & $\begin{array}{l}\text { Amerika } \\
\text { Serikat }\end{array}$ & $\begin{array}{l}\text { Kolaborasi antara } \\
\text { teknologi, } \\
\text { kesehatan, dan } \\
\text { pertanian }\end{array}$ & $\begin{array}{l}\text { Grameen } \\
\text { Intel }\end{array}$ \\
\hline Otto $\mathrm{GmbH}$ & Jerman & $\begin{array}{l}\text { Tekstil dan } \\
\text { pemberdayaan } \\
\text { energi konservasi }\end{array}$ & $\begin{array}{l}\text { Otto } \\
\text { Grameen }\end{array}$ \\
\hline Adidas & Jerman & Pendidikan & $\begin{array}{l}\text { Grameen } \\
\text { Adidas }\end{array}$ \\
\hline
\end{tabular}

Sumber: Muhammad Yunus, "Bisnis Sosial - Sistem Kapitalisme Baru yang Memihak Kaum Miskin", 2010. Data sudah diolah penulis.

Kerjasama Yunus dengan korporasi asing lain, juga diakui oleh Dr. Michael Otto, pemilik Otto GmbH, yang amat berminat untuk membantu meluncurkan sebuah bisnis sosial dalam kemitraan dengan Grameen (Kantjono, 2011: 206). Dr. Otto telah berbuat banyak untuk mendukung konsep usaha yang berkelanjutan, sehingga korporasinya di bidang tekstil akan sangat menarik jika ikut aktif berkontribusi dalam pemecahan masalah ekonomi-sosial di Bangladesh. Michael Otto yakin bahwa Grameen Otto akan menjadi perusahaan yang dapat menyelaaskan kriteria ekologi dan sosial dengan tujuan ekonomi.

Hal ini merupakan upaya Yunus dalam menjaga keseimbangan antara aspek ekonomi, sosial-budaya, dan lingkungan hidup pada proses pembangunan di tingkat grass root Bangladesh. Dalam bukunya Bisnis Sosial, Muhammad Yunus menegaskan bahwa perusahaan yang ikut serta dalam Bisnis Sosial adalah perusahaan tanpa rugi dan tanpa deviden yang diabdikan untuk memecahkan masalah sosial. (lihat Tabel 3)

Jenis Bisnis Sosial lain (kedua) yang ditawarkan oleh Yunus adalah perusahaan pencari laba dengan kepemilikan oleh penduduk miskin, baik kepemilikan secara langsung maupun melalui sebuah perwalian yang secara khsusus dibentuk demi suatu alasan sosial. Sesuai dengan prinsip Bisnis Sosial bahwa tujuannya adalah mengatasi kemiskinan, atau masalah lain yang mengancam manusia dan masyarakat dan bukan untuk memaksimalkan keuntungan.

Korporasi di atas memainkan peran barunya sebagai bisnis sosial yang bekerja demi masyarakat miskin dan keseimbangan lingkungan. Menjadi sebuah kepuasan tersendiri bagi setiap pemilik korporasi ketika masalah sosial memiliki progres penurunan yang baik di Bangladesh. Lebih jelasnya akan dibahas pada pemaparan selanjutnya.

Bisnis sosial pertama yang dibentuk oleh Yunus adalah Grameen Danone dan mulai berjalan di awal tahun 2007. Danone merupakan sebuah korporasi dari Prancis yang berkomitmen untuk memusatkan perhatian kepada masalah gizi di Bangladesh. Danone menjawab kekhawatiran atas kegagalan pembangunan berkelanjutan pada masyarakat yang semakin tidak mampu untuk meningkatkan kualitas kehidupan (Keraf, 2002: 169). Mutu kehidupan yang semakin menurun mengakibatkan datangnya berbagai penyakit. Ini menjadi bumerang bagi kaum miskin Bangladesh. Setengah diantara anak-anak di Bangladesh, terutama di kawasan pedesaan, menderita kekurangan gizi sehingga kualitas hidup meraka sangat rendah. Diare, yang biasanya hanya sebagai sebuah akibat awal kekurangan gizi, di Bangladesh justru menjadi penyakit yang sering berujung pada kematian. Kehadiran Danone sebagai jalan keluar bagi permasalahan kesehatan dan peningkatan kualitas hidup.

Kekurangan kualitas hidup - kesehatan - seperti ini menyebabkan sejumlah masalah dan efek domino. Dalam jangka panjang, masalah-masalah tersebut berimplikasi terhadap prospek pembangunan ekonomi yang akan mengalami penurunan. Disebabkan anakanak yang tidak sehat, sehingga sulit dikembangkan 
menjadi orang dewasa yang berpendidikan dan produktif.

Usaha patungan antara Grameen dan Danone ini menghasilkan produk Youghurt, dengan kandungan vitamin yang kompleks, rasa yang disukai anak-anak, dan tentunya dengan harga yang sangat rendah (dalam jangkauan penduduk miskin di Bangladesh).

Mengingat bahwa Youghurt juga merupakan makanan tradisional di Bangldesh dan dikembangkan oleh Danone sebagai sebuah susu dengan bahan-bahan vitamin, kalsium, dan protein, sehingga lebih mudah untuk diterima. Grameen Danone berhasil menurunkan jumlah kasus anak sakit, meningkatkan tingkat energi anak-anak, dan menaikkan angka kesetaraan mereka dalam kegiatan yang produktif.

Grameen Danone memberdayakan 'ibu-ibu Grameen' dalam membentuk sebuah jaringan penjualan bagi penduduk miskin di sekitar. Hal ini menjadi bentuk nyata atas empowering women in rural area. Ibu-ibu tersebut akan mendapatkan penghasilantambahan dari penjualan Youghurt. Selain membantu dalam aspek ekonomi dan kesehatan, perempuan pedesaan juga terlatih untuk melakukan bisnis secara mandiri (Grameen Danone Foods, 2012).

Lebih detail, laporan Grameen Danone Foods, sebuah perusahaan yang didedikasikan untuk pembangunan lingkungan memiliki empat fokus kerja. Petama, menyediakan sebuah produk dengan nilai nutrisi yang tinggi dan terjangkau untuk kaum miskin. Kedua, memperbaiki taraf kondisi kehidupan masyarakat miskin dengan menyediakan pekerjaan yang dapat meningkatkan standar hidup. Ketiga, melindungi lingkungan dan melakukan konnservasi sumber daya. Keempat, memastikan adanya pembangunan yang berkelanjutan dengan tetap mendapat keuntungan.

Konsep sustainable development mengkritisi kehadiran industri Barat, seperti pendirian pabrik, yang sedikit banyak menghasilkan masalah-masalah serius seperti pencemaran sungai, pencemaran udara, banjir, dan lain sebagainya. Daerah pedesaan di Bangladesh terutama mengidap masalah pencemaran sungai yang berimbas pada ketersediaan air minum bersih bagi rakyat miskin. Menurut penelitian yang telah dilakukan oleh CEO Grameen Shikkha, air di sumur-sumur gali atau sumur bor dangkal di seluruh Bangladesh memiliki kadar arsenikum, racun dalam air, yang melebihi ambang batas dan dalam jangka panjang akan merusak kesehatan manusia.

Veolia Water hadir berperan membantu Grameen dan penduduk miskin di Bangladesh dalam penanganan masalah ini. Veolia Water adalah bagian dari sebuah perusahaan lebih besar, Veolia Environment di Prancis, yang mengoperasikan sistem-sistem manajemen limbah, sistem efisensi energi, sistem transportasi umum, dan sistem-sistem air bersih. Di Bangladesh, Veolia Water berfokus pada layanan perancangan, pembangunan, dan pengelolaan air bak air bersih maupun air limbah untuk pemerintah dan untuk industri. Namun, di akhir tahun 2007, Veolia Water bekerjasama dengan Grameen Healthcare guna menyediakan air minum bersih bagi penduduk miskin di Bangladesh. Veolia Water telah berpengalaman dalam penyediaan air minum bersih di daerah-daerah miskin lain, seperti Afrika dan India.

Yunus menargetkan harga penjualan air olahan - air bersih - dari Grameen Veolia Water sebesar satu taka per sepuluh liter. Sehingga, penduduk miskin tidak merasa keberatan dalam mengkonsumsi air tersebut. Harga menjadi sebuah pertimbangan matang bagi Bisnis Sosial dalam perkembangannya. Muhammad Yunus juga menyediakan marjin laba bagi agen-agen penjualan yang bertugas menjual air, yaitu tim perempuan setempat "ibu-ibu Grameen" yang saat itu berjumlah sebelas orang, menjual air kepada temanteman dan tetangga-tetangga mereka di desa. Grameen Veolia Water berperan dalam peningkatan pendapatan bagi perusahaan Veolia sendiri dan para agen penjual air di desa-desa, selain tujuan utamanya terpenuhi yaitu mengurangi pencemaran lingkungan hidup, khususnya air.

Masih dalam konteks lingkungan dan kesehatan. Bisnis Sosial melakukan usaha patungan dengan salah satu perusahaan asing yang bergelut dalam bidang tekhnologi dari Jerman, BASF. Korporasi ini melakukan investasi di Bangladesh dalam membuat kelambu anti nyamuk dan menjual mikronutrien 
kesejahteraan ekonomi dan sosial-budaya yang sama seperti sekarang.

Aspek ketiga yang harus dipenuhi dalam pembangunan yang berkelanjutan adalah aspek lingkungan hidup. Sebuah korporasi yang berdiri seharusnya memperhitungkan nilai ekologis dan tidak terpaku pada nilai ekonomis saja. Aspek utama dari cita-cita pembangunan berkelanjutan telah tercantum pada poin ke-lima dari prinsip Binsis Sosial yang dirumuskan oleh Muhammad Yunus dengan Hans Reitz, direktur Grameen Creative Lab di Jerman, bahwa perusahaan dituntut untuk bersikap ramah kepada lingkungan (Kantjono, 2011: 3)

Sebagai contoh adalah bentuk usaha patungan Grameen Trust dengan Otto GmbH, sebuah perusahaan perdagangan dalam bidang tekstil. Bisnis Sosial ini akan disebut Otto Grameen Textile Company, sebuah bisnis yang beorientasi laba. Meski demikian, pabrik pakaian jadi Otto Grameen Textile Company akan dibuat berkelanjutan secara ekologi dan secara ekonomi. Tim yang bertugas membuat rencana terperinci melakukan penelitian dalam menentukan pilihan-pilihan optimal untuk bahan bangunan, konsumsi energi, dan manajemen rantai pasokan. Panel-panel surya akan digunakan untuk menyumbang kebutuhan energi pabrik sebanyak mungkin, ditambah seperlunya menggunakan sumber konvensional.

Gaya pembangunan pabrik yang dilakukan oleh Grameen Otto Textile ini berusaha memaksimalkan efisiensi dan meminimalkan emisi karbon. Pendingin ruangan, misalnya, menggunakan penempatan jendela yang memungkinkan terjadinya ventilasi silang sehingga dapat meminimalkan kegerahan selama musim kemarau. Selanjutnya, pendirian pabrik tekstil ini juga mempertimbangkan aspek sosial-kesejahteraan buruh yang bekerja. Selain upah yang wajar dan tunjangan kerja normal, manfaat sosial lain yang ditawarkan oleh Otto Grameen mencakup: akses makanan yang sehat dan bergizi, pelayanan kesehatan, bantuan pendidikan dan pelatihan kerja, akses ke kredit, bantuan untuk perumahan, prospek kepemilikan individual atau virtual bagi karyawan perusahaan. 


\section{Kesimpulan}

Keberlanjutan Grameen Bank tidak hanya terjadi dan tumbuh di Bangladesh, namun banyak negara lain baik negara maju maupun negara berkembang yang mengimplementasikan konsep Yunus. Grameen Bank hadir di beberapa negara di dunia, seperti Amerika, Mexico, Peru, Dominica, Egypt, Ghana, India China, Saudi Arabia, Filipina, dan lain sebagainya.

Adanya sikap kehati-hatian dalam menentukan langkah pembangunan, sesungguhnya telah menjamin bahwa cita-cita pembangunan berkelanjutan dapat dicapai. Melihat kolaborasi usaha patungan antara Grameen Bank dengan korporasi asing, menjadikan tolak ukur keberhasilan dan kemajuan masyarakat tidak lagi hanya berdasarkan kemajuan ekonomi. Bisnis Sosial mengajarkan bahwa tolak ukur keberhasilan adalah kualitas kehidupan yang dicapai dengan menjamin kehidupan ekologis, sosial-budaya, ekonomi secara proporsional. Dalam konteks pembangunan yang berkelanjutan, sistem Bisnis Sosial telah bekerja dengan baik dengan memberikan kesejahteraan bagi mayarakat, memberikan peluang yang sama, dan tidak lupa memperhatikan aspek sosialbudaya dan lingkungan hidup dalam pencapian aspek ekonomi.

\section{BIBLIOGRAFI}

\section{BUKU}

Budiman, Arie. Teori Pembangunan Dunia Ketiga. Jakarta: PT. Gramedia Pustaka Utama, 1995.

C. Korten, David. "The Post-Corporate World". Translated by A. Rahman Zainuddin. Jakarta: Yayasan Obor Indonesia, 2002.

Keraf, A. Sony. Etika Lingkungan. Jakarta: PT. Kompas Media Nusantara, 2002.

Kunio, Yoshihara, "Kapitalisme Semu Asia Tenggara". Translated by A. Setiawan Abadi. Jakarta: LP3ES, 1990.

Shiva, Vandana. "Bebas Dari Pembangunan - perempuan, ekologi dan perjuangan hidup di India". Translated by Hira Jhamtani. Jakarta: Yayasan Obor Indonesia, 1997.

Yunus, Muhammad. "Bank Kaum Miskin". Translated by Irfan Nasution. Tanggerang Selatan: CV. Marjin Kiri, 2007. . "Bisnis Sosial-Sistem Kapitalisme Baru yang memihak Kaum Miskin". Translated by Alex Tri Kantjono.Jakata: PT. Gramedia Pustaka Utama, 2011.

Jurnal - Makalah

Beim, David O. 2004. "Grameen Bank: Taking Capitalism to the Poor". Chazen Web Journal of International Buisness, Spring 2004. 2.

Cesselin, Marlon, "The Grameen Veolia Water Social Business." ESSEC
Business School, (http://lles.essec.edu, diakses 30 Oktober 2014)

Esty, Katharine. 2011. "Lesson from Muhammad Yunus and the Grameen Bank." OD PRACTITIONER. Vol. 43 No. 1, 2011.

Khandker, Shahidur - Bqui Khalily - Zahed Khan. 1994. "Is The Grameen Bank Sustainable?". Human Resources Development and Operations Policy. Februari 1994, 8-9.

Mahmud, Wahiduddin. 2008. "Social Development in Bangladesh: Pathways, Surprises and Challenges". Indian Journal of Human Development, Vol. 2 No. 1, 2008.

Mujeri, Mustafa K. 2002. Bangladesh: Bringing Poverty Focus in Rural Infrastructure Development. Geneva: International Labor office, Recovery and Reconstruction Department.

Yunus, Muhammad - Bertrand Moingeon - Laurence Lehman-Ortega. 2010. "Building Social Business Models: Lessons from the Grameen Experience." Long Range Planning 43. 308-325.

Website

"Credit, Shared Human Right" Review by The Times, (http:// www.grameen-info.org/index, diakses 30 Oktober 2014.)

"Grameen Intel Social Business Ltd." (http:// www.muhammadyunus.org/, diakses 29 Oktober 2014)

"Microcredit and Grameen Bank" New Internationalist People, Ideas, and Action for Global Justice, (http://newint.org, diakses 30 Oktober 2014)

"Muhammad Yunus on Capitalism" (http://www.youtube.com/, diakses pada 26 Oktober, 2014)

"The Nobel Prizefor 2006 to Muhammad Yunus and Grameen BankPress Release." Nobel Media AB 2014, (http://www.nobelprize.org, diakses 24 Oktober 2014)

"The Project's History" Grameen Danone Food Ltd, (http:// www.danonecommunities.com/, diakses 30 Oktober 2014)

Dwi Mudianingsih, "Pemberdayaan Masyarakat dan Wirausaha - Cara Kreatif Gali PotensiBisnis", Republika, 17 September 2014,

(http://www.republika.co.id/, diakses 30 Oktober 2014)

Elkingtion, John. "Chairmdns of strategy consultants sustain Ability by The Guardian" Review Business Social, (http:// www.grameeninfo.org/, diakses 30 Oktober 2014)

Hungry Mind Review (http://www.grameen-info.org/index, diakses 31 Oktober 2014).

Lingkup dan Definisi Pembangunan Berkelanjutan (Sustainable Development) (http://www.forexbroker.web.id/, diakses 30 Oktober 2014)

Streubig, Andreas. "Factory of the Future" The Otto Grameen Textile Company, (http://csr- manager.org/, diakes 30 Oktober 2014) Yunus Center - Not for Profit. (http://www.muhammadyunus.org/, diakses pada 30 Oktober 2014). 